\title{
PELATIHAN PENGOLAHAN SAMPAH ORGANIK BAGI MASYARAKAT DESA TLUTUP, KECAMATAN TRANGKIL, KABUPATEN PATI
}

\author{
Oleh: \\ Sri Murtini ${ }^{1}$, Agus Sutedjo $^{2}$, Ketut Prasetyo ${ }^{3}$, Murtedjo $^{4}$ \\ Jurusan Pendidikan Geografi, Universitas Negeri Surabaya \\ srimurtini@unesa.ac.id
}

\begin{abstract}
Abstrak
Sampah merupakan masalah klasik di masyarakat, termasuk di Desa Tlutup. Pengolahan sampah yang benar dapat membantu menjaga lingkungan dan memberi manfaat ekonomi. Tujuan kegiatan ini adalah untuk mengetahui pemahaman masyarakat tentang proses mengolah sampah organik menjadi kompos dan mengetahui respon masyarakat terhadap kegiatan pengolahan sampah organik menjadi kompos. Kelompok sasaran kegiatan ini adalah masyarakat yang terdiri dari ibu-ibu rumah tangga, karang taruna, dan perangkat desa yang berjumlah 50 warga. Kegiatan ini dilakukan pada tanggal 14 Juli 2019 di Desa Tlutup, Kecamatan Trangkil, Kabupaten Pati. Pelatihan menggunakan komposisi 30\% berupa pengenalan dan teori, serta $70 \%$ berupa praktek dan pemberian tugas. Teknik dan instrumen yang digunakan, yaitu pretest dan postest, angket dan observasi. Aspek yang dinilai meliputi proses dan hasil. Sedangkan kriteria keberhasilan, bila minimal $75 \%$ peserta memahami dengan baik dan minimal $75 \%$ peserta memberi respon positif. Hasil kegiatan menunjukkan bahwa sebagian besar peserta memahami dengan baik tentang materi kegiatan. Disamping itu, hasil kegiatan menunjukkan bahwa masyarakat Desa Tlutup memberikan respon yang positif terhadap pelatihan. Bagi masyarakat yang sudah memahami diharapkan membantu memahamkan masyarakat yang belum paham. Disamping itu, bagi pemerintah desa harus mendukung program seperti mendanai pembelian peralatan dan mengkoordinir pengepulan sampah anorganik.
\end{abstract}

Kata Kunci: pengolahan sampah, sampah organik, masyarakat desa

\begin{abstract}
Waste is a classic problem in society, including in Tlutup village. Proper waste processing can help maintain the environment and provide economic benefits. The purpose of this activity is to know the understanding of people about the process of organic waste into compost and know the public response to this activitiy. The target group of activity is a community consisting of housewives, youth organization, and village apparatus amounting to 50 residents. This activity was conducted on 14 July 2019 in Tlutup village, Trangkil Subdistrict, Pati District. Training using by the composition of $30 \%$ in introduction and theory's form, and $70 \%$ in the form of practice and assignment. The techniques and instruments used are pre-test and posttest, poll, and observation. Assessed aspects include processes and results. Meanwhile, the success criteria for at least $75 \%$ of participants understand well and at least $75 \%$ of participants gave a positive response. Results showed that most participants understood well about the activity material. In addition, the results show that Tlutup village community provides a positive response to training. For people who already understand it is expected to help the hang of people who do not understand. In addition, the village government should support programs such as funding equipment purchases and coordinating the pining of anorganic waste.
\end{abstract}

Keywords: waste processing, organic waste, villagers

\section{PENDAHULUAN}

Pengelolaan sampah di pedesaan memiliki karakteristik yang khas dimana masyarakat pada umumnya membuang sampah di tempat lubang pembuangan sampah yang sudah disediakan oleh masingmasing rumah tangga. Lubang sampah ini biasanya berukuran kurang lebih $2 \times 1$ meter dengan kedalaman 1 meter dan terletak di belakang rumah. Lubang sampah tersebut akan penuh kurang lebih 2-3 bulan, dan kalau sudah penuh maka akan ditutup begitu saja dengan tanah dan selanjutnya akan berpindah untuk membuat lubang sampah di tempat yang baru, begitu seterusnya. Kebiasaan masyarakat yang demikian ini sudah berlangsung sejak dahulu kala, seolah menjadi suatu budaya karena dilakukan terus menerus dan turun temurun. 
Di samping itu, masyarakat juga mempunyai kebiasaan untuk tidak memilah sampah yang dihasilkan dari rumah tangga. Kebiasaan ini umum terjadi di semua masyarakat baik desa maupun kota. Padahal pemilahan sampah merupakan hal yang sangat penting untuk dilakukan oleh semua orang. Pemilahan sampah di rumah adalah komponen kunci dalam upaya untuk mengalihkan sampah dari TPA dan untuk memaksimalkan pencarian sampah yang masih bisa didaur ulang.

Pemilahan sampah dari sumbernya mencakup beragam elemen penting, tidak hanya memberdayakan tiap individu untuk lebih mengetahui produk dan kemasan yang mereka konsumsi, tetapi juga memungkinkan kita untuk lebih peka terhadap sampah yang dihasilkan. Berdasarkan permen UU No. 3 Tahun 2013 menyatakan bahwa penanganan sampah dari sumbernya menjadi tanggung jawab bersama antara masyarakat dan pemerintah. Kondisi saat ini pemilahan sampah dari sumbernya belum memadai sehingga berbagai gerakan perlu ditingkatkan melalui peranan tokoh masyarakat, kelompok swadaya masyarakat atau pemerintah.

Namun kenyataannya, meyakinkan masyarakat untuk memilah sampah masih sulit, seperti yang kita amati di lingkungan sekitar bahwa masyarakat Indonesia tampaknya masih berkutat di fase "buanglah sampah pada tempatnya", belum naik level ke fase pemilahan dan mendaur ulang sampah. Marliani (2014) menyatakan bahwa pendidikan lingkungan hidup penting dalam upaya mengimplementasikan pemanfaatan limbah rumah tangga.

UU RI No. 18 Tahun 2008 mengatakan bahwa permasalahan sampah mencakup banyak aspek, oleh karena itu pengelolaannya perlu dilakukan secara komprehensif dan terintegrasi dengan inovasi-inovasi baru yang lebih memadai ditinjau dari segala aspek, baik itu aspek sosial, aspek ekonomi maupun aspek teknis dari hulu sampai ke hilir agar memberikan manfaat secara ekonomi, sehat bagi lingkungan, serta dapat mengubah perilaku masyarakat.

Dengan menjadi lebih proaktif dan terlibat dalam proses pemilahan, kita jadi lebih bisa fokus dalam menciptakan sistem yang lebih efisien untuk menggunakan kembali (reuse) dan daur ulang (recycle) sampah. Konsep daur ulang sampah atau yang biasa disebut juga dengan 3R (Reduce, Reuse, Recycle) merupakan salah satu solusi yang dapat dipertimbangkan, sehingga nilai ekonomis yang masih terkandung di dalam sampah dapat dimanfaatkan. (Riatno, 2007).

Atas dasar kondisi seperti tersebut maka tim PKM dari Unesa berusaha untuk ikut peduli dengan cara memberikan pengetahuan tentang pengelolaan sampah untuk menjadi kompos bagi warga masyarakat di Desa Tlutup agar mereka dapat ikut peduli terhadap kelangsungan lingkungan melalui serangkaian proses dari pengolahan sampah organik menjadi kompos. Tujuan kegiatan ini adalah untuk mengetahui pemahaman masyarakat tentang proses mengolah sampah organik menjadi kompos dan mengetahui respon masyarakat terhadap kegiatan pengolahan sampah organik menjadi kompos.

\section{METODE}

Kelompok sasaran pada kegiatan ini adalah masyarakat di Desa Tlutup yang terdiri dari ibu rumah tangga, karang taruna dan perangkat desa yang berjumlah 50 orang. Kegiatan ini dilakukan di Desa Tlutup, Kecamatan Trangkil Kabupaten Pati pada Juli 2019. Pelatihan menggunakan komposisi $30 \%$ berupa pengenalan dan teori, serta $70 \%$ berupa praktik dan pemberian tugas. Kegiatan pelatihan mengolah sampah organik menjadi kompos dilaksanakan dengan tahapan sebagai berikut: tahap pertama in service learning 1, tahap kedua on the job training, dan tahap ketiga in service learning 2 .

\section{Rancangan Evaluasi}

A. Kriteria Keberhasilan Kegiatan pengabdian kepada masyarakat ini dinilai berhasil apabila:

1. Minimum $75 \%$ masyarakat dapat memahami cara mengolah sampah organik menjadi kompos.

Kriteria penilaian:

$$
\frac{\text { skor total }}{\text { skor maksimal }} \times 100
$$

keterangan:

$$
\text { skor: }
$$

$>75$ = baik

$<75=$ kurang baik.

2. Minimum $75 \%$ masyarakat memberikan respon positif.

Kriteria penilaian:

keterangan:

$$
\frac{\text { skor total }}{\text { skor maksimal }} \times 100
$$

$>75=$ respon positif

$<75=$ respon negatif.

\section{B. Aspek yang Dinilai}


1. Proses yaitu hal-hal yang berhubungan dengan keseluruhan aspek perencanaan dan pelaksanaan yaitu: keaktifan peserta dalam mengikuti kegiatan, dukungan Pemerintah Desa, faktor penghambat dan pelancar kegiatan.

2. Hasil (adanya peningkatan pengetahuan masyarakat tentang mengelola sampah organik menjadi kompos dan peningkatan respon masyarakat dalam mengelola sampah organik menjadi kompos).

C. Teknik dan Instrumen

a. Pre-Test dan Post-test, untuk mengetahui pemahaman tentang mengelola sampah organik menjadi kompos.

b. Angket, untuk mengetahui respon masyarakat terhadap kegiatan pelatihan secara keseluruhan.

c. Observasi, untuk mengetahui kemampuan masyarakat mengelola sampah organik menjadi kompos.

\section{HASIL DAN PEMBAHASAN}

Pemahaman masyarakat dapat diketahui dengan menggunakan 10 (sepuluh) pertanyaan dengan 4 (empat) pilihan jawaban seperti pada Tabel 1. Hasil jawaban peserta akan mencerminkan tingkat pengetahuan masyarakat akan pengolahan sampah organik menjadi kompos. Secara lengkap, jawaban peserta atas pertanyaan yang diajukan adalah seperti berikut.

1) Ketertarikan terhadap materi pemilahan sampah

Jawaban peserta terhadap pertanyaan tentang dayatarik materi yang diberikan adalah sebanyak 28 peserta sangat tertarik, 18 peserta tertarik, tidak ada peserta yang kurang tertarik namun masih terdapat 4 peserta yang tidak tertarik terhadap materi yang diberikan. Skor yang diperoleh peserta kegiatan secara keseluruhan adalah $(28 \times 4)+$ $(18 \times 3)+(4 \times 2)=174$.

2) Materi yang disampaikan

Jawaban peserta merasa sangat mudah sebanyak 19 , mudah sebanyak 28 peserta, terdapat 3 peserta yang merasa sulit, dan tidak ada yang merasa sangat sulit. Skor yang diperoleh peserta kegiatan secara keseluruhan adalah $(19 \times 4)+(28 \times 3)+(3 \times 2)=$ 166.

3) Penjelasan materi

Sebanyak 18 peserta menjawab sangat mudah, 30 peserta menjawab mudah, terdapat 2 peserta yang menjawab sulit dipahami dan tidak ada peserta yang menjawab sangat sulit untuk memahaminya. Dengan demikian skor kegiatan secara keseluruhan adalah sebesar $(18 \times 4)+(30 \times 3)+$ $(2 \times 2)=166$.

4) Pemilahan sampah rumah tangga

Jawaban peserta kegiatan untuk melakukan pemilahan sampah rumah tangga adalah 24 peserta menjawab sangat mudah, 21 peserta menjawab mudah, namun masih terdapat 5 peserta yang masih kesulitan melakukan pemilahan dan tidak terdapat peserta yang sangat sulit melakukan pemilahan sampah. Skor peserta kegiatan secara keseluruhan tentang pemilahan sampah adalah $(24 \times 4)+(21 \times 3)+(5 \times 2)=169$

5) Kejelasan materi yang disampaikan

Berdasarkan jawaban peserta kegiatan tentang kejelasan materi yang disampaikan maka 17 peserta menjawab sangat jelas, 28 peserta menjawab jelas, namun masih terdapat 5 peserta yang menjawab tidak jelas dan tidak ada peserta yang menjawab sangat tidak jelas. Skor yang diperoleh peserta kegiatan secara keseluruhan untuk kejelasan materi adalah $(17 \times 4)+(28 \times 3)+(5 \times 2)=162$.

$6)$ Demonstrasi yang disampaikan

Peserta yang menjawab sangat mudah sebanyak 11 orang, menjawab mudah sebanyak 35 orang, namun masih terdapat 4 orang yang menjawab sulit untuk mempraktekkannya, dan tidak ada yang menjawab sangat sulit untuk mempraktekkan kembali. Skor yang diperoleh peserta secara keseluruhan adalah $(11 \times 4)+(35 \times 3)+(4 \times 2)=$ 157.

7) Contoh sampah organik

Skor yang diperoleh peserta kegiatan tentang pengetahuan sampah organik adalah sebesar $50 \times 4=200$.

8) Contoh sampah non organik

Dari hasil test yang dilakukan sebagian besar sudah mengetahui bahan-bahan sampah non organik, yakni 45 peserta menjawab dengan benar contoh-contoh sampah non organik yang diberikan, namun masih terdapat 5 peserta yang salah dalam memilih jawaban dengan memilih 1 sampah jenis organik dimasukkan dalam jenis non organik yaitu bangkai. Skor yang diperoleh peserta kegiatan untuk contoh untuk sampah non organik adalah $(45 \times 4)+(5 \times 3)=190$.

9) Pencampuran obat/ ragi dengan sampah

Dari 50 peserta kegiatan sebanyak 38 orang berpendapat bahwa pencampuran harus sesuai aturan, 7 orang berpendapat 
bahwa makin banyak obat makin baik hasilnya, sedangkan 5 orang berpendapat bahwa pencampuran obat/ragi harus memperhatikan waktu kadaluwarsa. Skor yang diperoleh peserta kegiatan secara keseluruhan untuk aspek pencampuran obat dengan air adalah $(38 \times 4)+(7 \times 3)+(5 \times 1)=$ 178.

10) Pemanfaatan kompos

Sebanyak 34 peserta mengetahui bahwa pupuk kompos siap untuk digunakan apabila warna air lindi yang keluar sudah mulai berwarna jernih, 12 peserta berpendapat bahwa kompos siap digunakan apabila prosesnya sudah berjalan 4 bulan, 4 peserta berpendapat bahwa kompos siap digunakan apabila obat pencampur/ habis 1 botol. Skor yang diperoleh peserta kegitan secara keseluruhan tentang waktu pemanfaatan kompos adalah $(34 \times 4)+(12 \times 3)+(4 \times 1)=176$.

Skor pemahaman tentang pengolahan sampah organik menjadi kompos bagi peserta kegiatan secara total adalah $174+166+166$ $+169+162+157+200+190+178+176=$ 1538. Skor total tersebut selanjutnya dimasukkan ke dalam kategori pemahaman yang telah dibuat, apabila skor maksimalnya adalah 2000, maka hasil perhitungan untuk nilai pemahaman adalah $(1538: 2000) \times 100=$ 76,9 . Nilai ini termasuk kategori baik, karena lebih dari 75.

Respon masyarakat terhadap kegiatan pengolahan sampah di Desa Tlutup dengan menggunakan 5 butir pertanyaan dengan 4 pilihan jawaban. Hasil pengolahan data pada Tabel 2. menunjukkan respon seperti berikut.

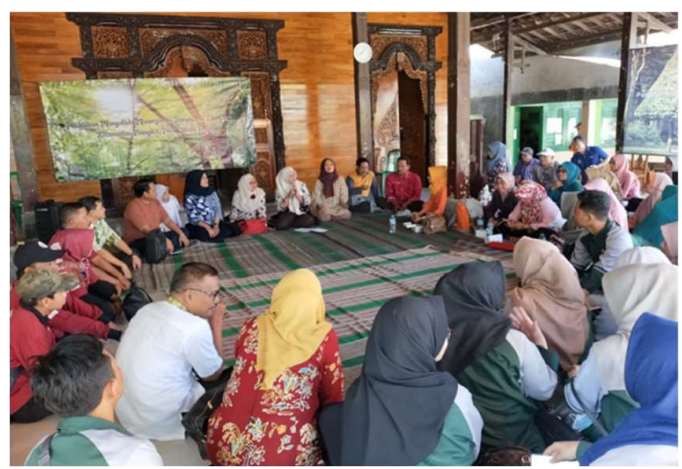

Gambar 1. Penyampaian materi kepada warga Desa Tlutup, Trangkil, Pati

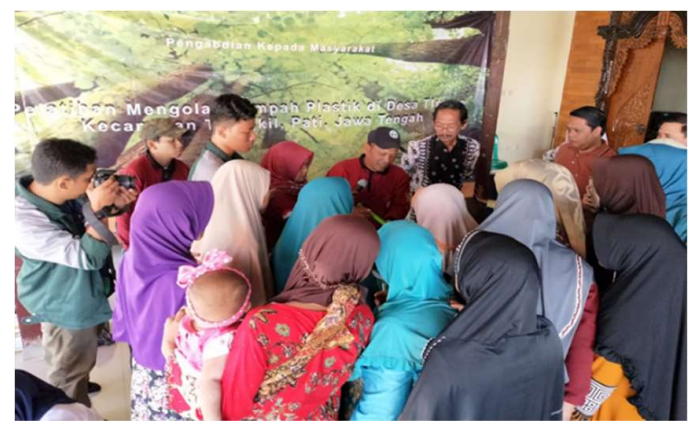

Gambar 2. Praktik pengolahan sampah

Tabel 1. Pemahaman Masyarakat Terhadap Materi Kegiatan

\begin{tabular}{|c|c|c|c|c|c|c|}
\hline \multirow{2}{*}{ No. } & \multirow{2}{*}{ Pertanyaan } & \multirow[t]{2}{*}{ Keterangan } & \multicolumn{4}{|c|}{ Jawaban (Skor) } \\
\hline & & & (4) & (3) & (2) & Jumlah \\
\hline 1 & Manfaat kegiatan & Ketertarikan & 28 & 18 & 4 & 174 \\
\hline 2 & $\begin{array}{l}\text { Kesediaan mengikuti } \\
\text { pelatihan lanjutan }\end{array}$ & Kemudahan & 19 & 28 & 3 & 166 \\
\hline 3 & $\begin{array}{l}\text { Kesediaan pemilahan } \\
\text { sampah RT }\end{array}$ & Kejelasan & 18 & 30 & 2 & 166 \\
\hline 4 & Praktek membuat kompos & Kali & 24 & 21 & 5 & 169 \\
\hline 5 & $\begin{array}{l}\text { Kesediaan mengajarkan } \\
\text { ke orang lain }\end{array}$ & Kejelasan & 17 & 28 & 5 & 162 \\
\hline 6 & $\begin{array}{l}\text { Demontrasi yang } \\
\text { disampaikan }\end{array}$ & Kemudahan & 11 & 35 & 4 & 157 \\
\hline 7 & Contoh sampah organik & Benar & 50 & 0 & 0 & 200 \\
\hline 8 & Contoh sampah anorganik & Benar & 45 & 5 & 0 & 190 \\
\hline 9 & $\begin{array}{l}\text { Pencampuran obat ( R5) } \\
\text { dengan sampah }\end{array}$ & Ketepatan & 38 & 7 & 5 & 178 \\
\hline 10 & Pemanfaatan kompos & Kebermanfaatan & 34 & 12 & 4 & 176 \\
\hline
\end{tabular}


Tabel 2. Respon Masyarakat Terhadap Materi Kegiatan

\begin{tabular}{|c|c|c|c|c|c|}
\hline \multirow{2}{*}{ No. } & \multirow{2}{*}{ Pertanyaan } & \multicolumn{4}{|c|}{ Jawaban (Skor) } \\
\hline & & (4) & (3) & (2) & Jumlah \\
\hline 1 & Manfaat kegiatan & $\begin{array}{c}33 \text { sangat } \\
\text { bermanfaat }\end{array}$ & $\begin{array}{c}17 \\
\text { bermanfaat }\end{array}$ & 0 & 173 \\
\hline 2 & $\begin{array}{l}\text { Kesediaan mengikuti pelatihan } \\
\text { lanjutan }\end{array}$ & $\begin{array}{l}15 \text { sangat } \\
\text { bersedia }\end{array}$ & $\begin{array}{c}32 \\
\text { bersedia }\end{array}$ & $\begin{array}{c}3 \text { tidak } \\
\text { bersedia }\end{array}$ & 162 \\
\hline 3 & Kesediaan pemilahan sampah RT & $\begin{array}{l}22 \text { sangat } \\
\text { bersedia }\end{array}$ & $\begin{array}{c}28 \\
\text { bersedia }\end{array}$ & 0 & 192 \\
\hline 4 & Praktek membuat kompos & $\begin{array}{l}25 \text { langsung } \\
\text { praktek }\end{array}$ & $\begin{array}{c}21 \\
\text { menunggu } \\
\text { waktu }\end{array}$ & 4 ragu & 171 \\
\hline 5 & Kesediaan mengajarkan ke orang lain & $\begin{array}{l}16 \text { sangat } \\
\text { bersedia }\end{array}$ & $\begin{array}{c}31 \\
\text { bersedia }\end{array}$ & 3 ragu & 163 \\
\hline
\end{tabular}

1) Manfaat kegiatan

Dari 50 peserta kegiatan, 33 orang peserta merasakan sangat bermanfaat, 17 peserta merasakan bermanfaat atas kegiatan yang telah diikutinya. Skor peserta secara keseluruhan tentang manfaat kegiataan ini adalah $(33 \times 4)+(17 \times 3)=173$.

2) Kesediaan mengikuti pelatihan lanjutan

Respon peserta secara lebih detail adalah 15 peserta menyatakan sangat bersedia untuk mengikuti pelatihan lanjutan, 32 peserta menyatakan bersedia untuk mengikuti pelatihan lanjutan, sedangkan 3 peserta menyatakan tidak bersedia untuk mengikuti pelatihan laanjutan. Dengan demikian skor peserta kegiatan tentang kesediaan mengikuti pelatihan lanjutan adalah $(15 \times 4)+(32 \times 3)+(3 \times 2)=162$.

3) Permintaan untuk pemilahan sampah rumahtangga

Respon peserta kegiatan terhadap permintaan untuk pemilahan sampah rumah tangga cukup baik. Dari 50 peserta kegiatan sebanyak 22 orang sangat bersedia untuk memisahkan sampah organik dengan non organik setiap hari, sedangkan sisanya sebanyak 28 orang bersedia untuk melakukan pemilahan sampah rumah tangga. Dari aspek ini, skor peserta kegiaan secara keseluruhan adalan $(22 \times 4)+(28 \times 3)=192$.

4) Mempraktekkan pembuatan kompos

Respon responden terhadap permintaan untuk segera mempraktekkan beragam namun direspon secara positip. Dari 50 peserta kegiatan, sebanyak 25 orang akan segera mempraktekan sendiri dirumah, sedangkan 21 orang juga akan mempraktekkan namun mencari waktu luang terlebih dahulu, dan terdapat 4 orang yang masih memikirkan apakah dipraktekkan atau tidak. Tidak ada peserta kegiatan yang tidak ingin mempraktekkan pembuatan kompos, semuanya ingin mempraktekkan dengan pertimbangan masing-masing. Skor yang diperoleh dari aspek kesdiaan mempraktekkan ini adalah $(25 \times 4)+(21 \times 3)+$ $(4 \times 2)=171$.

5) Kesediaan untuk menularkan pengetahuan dan ketrampilan pembuatan kompos

Peserta kegiatan pada umumnya memberikan respon positip atas permintaan untuk menularkan pengalamannya. Dari 50 peserta kegiatan, 16 orang sangat bersedia untuk menularkan pengalamannya kepada orang lain, sedangkan 31 orang menyatakan bersedia untuk menlarkan pengalamannya, namun terdapat 3 orang yang menimbangnimbang apakah bersedia atau tidak untuk menularkan pengalamannya kepada tetangga terdekat atau orang lain. Dari aspek kesediaan menularkan pengalamannya, skor peserta kegiatan secara keseluruhan adalah $(16 \times 4)+(31 \times 3)+(3 \times 2)=163$.

Respon peserta kegiatan terhadap kegiatan pembuatan pupuk kompos yang telah diikutinya mempunyai skor total sebesar $173+162+192+171+163=861$. Skor total tersebut selanjutnya dimasukkan ke dalam kategori respon yang telah dibuat, apabila skor maksimalnya adalah 1000 , maka hasil perhitungan untuk nilai respon adalah $(861: 1000) \times 100=86,1$. Nilai ini termasuk kategori respon positif.

Nitikesari 2005), menyatakan terdapat faktor pendorong dan penghambat untuk meningkatkan partisipasi masyarakat seperti tingkat pendidikan, tempat sampah di rumah, keberadaan pemulung, peraturan tentang sampah. Sedangkan pendapat dari Adeyemi 
(2011), menyatakan perencanaan pada akhirnya tidak menjadi berkelanjutan karena masyarakat tidak merasakan tanggungjawab terhadap lingkungan.

Demonstrasi merupakan salah satu cara yang efektif dalam menyampaikan informasi, begitu pula tentang demonstrasi cara pembuatan pupuk kompos yang telah dilakukan oleh tim pengabdian. Pembuatan pupuk kompos menggunakan peralatan yang sederhana karena banyak dijumpai dan dengan cara yang tidak terlalu rumit sehingga mudah dipahami. Demonstrasi yang telah dilakukan cukup efektif hasilnya, hal itu terbukti dengan jawaban sebagian besar peserta bahwa mereka merasa mudah untuk mempraktikkan sendiri di rumah. Sehubungan dengan sebagian kecil jawaban peserta bahwa mereka akan kesulitan mempraktekkan kembali, hal ini dimungkinkan karena tidak ada praktek terlebih dahulu atau kurang memperhatikan dengan seksama pada waktu demonstrasi dilakukan. Namun hal ini tidak perlu dikhawatirkan karena antusias yang tinggi dari peserta untuk mengatasi masalah sampah dan banyak peserta lain yang siap membantu.

Pemahaman yang benar tentang jenisjenis sampah organik merupakan awal dari keberhasilan dalam proses pembuatan pupuk kompos. Selain pupuk kompos, dalam proses pembuatannya juga menghasilkan pupuk cair yang dapat digunakan untuk pemupukan juga. Kualitas dari pupuk cair ini juga tergantung dari jenis-jenis sampah organik yang digunakan sebagai bahan bakunya. Jenis sampah organik yang digunakan tidak hanya sampah rumah tangga saja akan tetapi dapat ditambahkan sampah dari tempat yang lain terutama segala macam bangkai untuk meningkatkan unsur tertentu yang sedikit terdapat dalam sampah rumah tangga. Pupuk cair tersebut merupakan hasil perlindian dari proses pembusukan sampah organik yang dapat dimanfaatkan untuk pemupukan tanaman. Dengan demikian, dalam proses pembuatan pupuk kompos juga akan dihasilkan pupuk cair sebagai produk sampingan.

Masyarakat desa Tlutup sebagian besar bermata pencaharian sebagai petani padi dan tambak sehingga pupuk yang dihasilkan dari proses pengolahan ini dapat membantu meringankan pengeluaran petani dan juga membantu menjaga kesuburan lahan. Pupuk cair yang dihasilkan dari lindi ini lebih aman, murah dan hasilnya lebih maksimal. Pupuk cair dapat menyuburkan tanah dan menumbuhkan klekap pada tambak sebagai bahan makanan ikan atau udang.

Sebagian besar masyarakat Desa Tlutup bermata pencaharian sebagai petani padi dan tambak sehingga pupuk yang dihasilkan dari proses pengolahan ini dapat membantu meringankan pengeluaran petani dan juga membantu menjaga kesuburan. lahan. Pupuk yang dihasilkan dari lindi ini lebih aman, murah dan hasilnya lebih maksimal, sementara modal yang digunakan untuk pembuatan pupuk relatih sedikit. Jika pupuk yang dihasilkan cukup banyak, atau tidak digunakan sendiri, dapat dijual untuk menambah pendapatan rumah tangga.

Tingkat keberhasilan masyarakat Desa Tlutup dalam mengolah sampah organik menjadi pupuk kompos dan pupuk cair diperkirakan tinggi karena hasil test tertulis menunjukkan bahwa semua peserta dapat mengetahui jenis sampah organik dengan benar. Pemahaman yang baik dari masyarakat tentang sampah organik disebabkan faktor kesehariannya yang selalu menangani sampah rumah tangga dan faktor pelatihan yang telah diikuti sehingga menambah luas wawasannya.

\section{SIMPULAN DAN SARAN}

Berdasarkan hasil analisis, pelaksana mendapatkan simpulan dan saran seperti berikut:

\section{Simpulan}

Terdapat beberapa simpulan yang dihasilkan dari kegiatan PKM ini, yaitu:

1. Sebagian besar masyarakat Desa Tlutup Kecamatan Trangkil Kabupaten Pati telah memahami dengan baik dengan nilai 76,9.

2. Sebagian besar masyarakat Desa Tlutup Kecamatan Trangkil Kabupaten Pati memberikan respon yang positif dengan nilai 86,1 .

\section{Saran}

Terdapat beberapa saran yang dapat digunakan sebagai rekomendasi untuk kegiatan PKM berikutnya, yaitu:

1. Perangkat desa harus mendukung dianataranya: menunjuk beberapa perwakilan warga, membeli sampah anorganik dan menyediakan deponya.

2. Monitoring secara berkala pembuatan sampah organik agar kegiatan ini dapat berkesinambungan. 


\section{DAFTAR PUSTAKA}

Adeyemi dan Oyienyi. 2011. Waste Management in Contemporary Nigeria: The Abuja Example. International Journal of Politics and Good Governance. v.2. no.2.2.

Badan Standardisasi Nasional. 2002. Tata Cara Teknik Operasional Pengelolaan Sampah Perkotaan SKSNI 19-2454-2002. Bandung: Yayasan LPM.

Kementerian Pekerjaan Umum. 2017. Petunjuk Teknis TPS 3R Tempat Pengolahan Sampah 3R Kementerian PU dan Perumahan Rakyat. Dirjen Cipta Karya Direktorat Pengembangan Penyehatan Lingkungan Pemukiman. http://plpbm.pu.go.id/v2/assets/file/Petunju kTeknisTPS3R2017.pdf (diunduh tanggal 16 Maret 2020).

PKLH UNUD. 2007. Kajian Sosial Kemasyarakatan Model Pengelolaan Sampah Di Lingkungan Pemukiman Perkotaan Di Provinsi Bali. Laporan Penelitian Kerjasama PPLH UNUD dengan PUSREG Bali-Nusra. Denpasar.

Marliani, Novi. 2014. Pemanfaatan Limbah Rumah Tangga (Sampah Anorganik)
Sebagai Bentuk Implementasi Dari Pendidikan Lingkungan Hidup. Jurnal Formatif 4(2): 124-132. https://journal.lppmunindra.ac.id/index.php /Formatif/article/download/146/140. (diunduh tanggal 11 Maret 2020).

Nitikesari, Putu E. 2005. Analisis Tingkat Partisipasi Masyarakat dalam Penanganan Sampah Secara Mandiri di Kota Denpasar. Tesis Magister Program Pascasarjana Universitas Udayana. Denpasar.

Riatno, dkk. 2007. Studi Evaluasi Pengelolaan Sampah dengan Konsep $3 R$ (studi kasus: Kec. Cilandak, jakarta Selatan). Jurnal Teknologi Lingkungan Vol. 4 no. 1, ISSN. 1829-6572.

Soewedo dan Hadiwiyoto. 1983. Penanganan dan Pemanfaatan Sampah. Jakarta: Yayasan Idaya.

Tapasya dan Surayasa. 2012. Studi Evaluasi Pengelolaan Sampah Dengan Konsep $3 R$ (Reduce, Recycle, Reuse). Volume 21 No.1 hal.15.

Undang-Undang No. 18 Tahun 2008 tentang Pengelolaan Sampah. 